\title{
Welfare in Danish Dairy Herds 2. Housing Systems and Grazing Procedures in 1983 and 1994
}

\author{
By L. Alban and J.F. Agger
}

Department of Anımal Science and Anımal Health, Division of Ethology and Health, The Royal Veterınary and Agricultural Unıversıty, Frederıksberg, Denmark

\begin{abstract}
Alban, L. and J. F. Agger. Welfare in Danish dairy herds 2. Housing systems and grazing procedures in 1983 and 1994. Acta vet. scand. 1996, 37, 65-77. This paper presents the second part of a questionnaire survey carried out in 2148 Danish dairy herds durıng 1994, as well as results from a simılar survey carried out in 1983 The welfare status and trends during the 11 year period are discussed with respect to cattle housing systems and grazıng procedures Generally speakıng, the results show that Danısh dairy farmers in 1994 followed the common recommendations, 1 e 1) there are partitions between stalls in almost all tie stall houses, 2) feeding cubicles are seldomly seen in cubicle houses, 3 ) bedding is provided for most cows, 4) saw dust as bedding for cows is not commonly used, and 5) the majority of cows and heifers are pastured during summer However, adjustments in the following areas would be appropriate: 1) tie systems which restrict the cow's natural rising and lying should be phased out, and 2) loose housed heifers in boxes should have access to a bedded restıng area
\end{abstract}

cattle; animal welfare; behaviour; health; questionnaires; surveys; descriptive epidemiology.

\section{Introduction}

The economic and competitıve developments characterizing intensive dairy industry inevitably have an impact on production, housing, and management. Examples thereof in Denmark are increased labour costs, increased milk production per cow, and increased herd size for herds remaining in business. And also due to milk quotas introduced in 1984, the number of dairy cows have declined. The current discussion in Denmark focuses on the possible impact of this development on cow welfare (Anon. 1988a, Tinggaard 1994). Studies by Agger (1981, 1983) and Agger \& Willeberg (1991) indicate, under Danısh conditions, relationships between current developments in housing, management, and productivity, and increased mortality in dairy cows from 1960 to 1991 .
Simonsen (1993) defined welfare to be the sum of positive and negative experiences that an animal has. As examples of substantial negative experiences Simonsen (1993) stated pain, fear, and frustration, and as substantial positive experiences joy, play, and satisfied expectations. Under climatic conditions like the Danish, dairy cattle are housed generally 6 months a year. Therefore, the housing system and grazing procedures inevitably have a great impact on the experiences of the cows.

The aim of the present paper is to discuss the welfare status in Danish dairy herds with respect to housing systems and grazing procedures. Information about housing systems, grazing procedures, and management routines in Danish dairy herds was last gathered in 1983 from 156 dairy herds and in large scale in 1988 
from 12,096 dairy herds (Anon. 1988b). Results from a 1994 survey carried out in 2148 Danish dairy herds selected in Ringkøbing County, Funen County, and around the city of Brørup, as well as results of the 1983 survey are presented. Disease management routines and welfare are dealt with in another paper (Alban \& Agger 1996), and health management and general procedures are dealt with in a third paper (Agger \& Alban 1996).

The questionnaire survey was carried out as a part of the research project "Welfare in dairy cows" funded by the Danish Ministry of Agriculture.

\section{Materials and methods}

This publication and the publications by Alban \& Agger (1996) and Agger \& Alban (1996) are based on 2 data sets collected in 1983 and in 1994. The results from the 1983-study in 152 tie stall herds will be given in the text and from the 1994-study of 2148 dairy herds primarily in tables. The materials and methods for both surveys are described in detail in Alban \& Agger (1996). The results of the 1994 survey will be compared to the 1983 survey and a large survey carried out in 1988 (Anon. 1988b), and trends during the 11 year period will be discussed. Furthermore, the results of the 1994 survey will be compared to the general recommendations for cattle keeping. In case there was a significant association between a variable and type of housing, this is stated. The statistical evaluation was done by use of Chi-square test and Pearson standardized residual analysis (Christensen 1990).

\section{Results}

The 1983 study

A sample of 156 farms in East Denmark showed that 152 had tie stall houses $(97.4 \%)$, only 3 herds $(1.9 \%)$ had cubicle houses, and 1 had deep bed house $(0.6 \%)$. In the tie stall herds the 3 most commonly used tie systems were ash wood / double chain tie $(22.5 \%)$, vertical chain tie with tight neck tie $(23.0 \%)$ and vertical chain tie with loose neck tie (21.7\%). 9.2\% had yoke tie, 9.2\% used neckbar tie, and $14.4 \%$ used other ties. Cow trainers were present in almost all herds $(79.9 \%)$. Half of the farmers $(56.1 \%)$ turned the power on the cow trainers more than 21 days per month, and the other half (43.9\%) less than 21 days per month. On a da1ly basis $31.5 \%$ turned it on for less than $9 \mathrm{~h}$, $22.1 \%$ turned it on for $9-16 \mathrm{~h}$, and $46.4 \%$ during more than $17 \mathrm{~h}$. In the majority $(53.0 \%)$ of the herds, partitions were only present between every 2 cows, between all cows in $33.4 \%$ of the herds, in $5.3 \%$ less frequent, and in the rest $(8.3 \%)$ of the herds there were no partitions at all. The majority (87.3\%) of the tie stall houses had a traditional open dung channel, while the rest $(12.7 \%)$ either had the dung channel covered with gratings or slats. Almost all (96.0\%) farmers had the cows on concrete floor, and only $4.0 \%$ on bricks in very old stalls. Concrete floor with long straw bedding was commonly used $(80.8 \%$ ), and $7.6 \%$ used long straw upon rubber matts. Only $2.7 \%$ used chopped straw on concrete, and $2.5 \%$ on rubber matts. Only $1.2 \%$ used saw dust on concrete, $3.8 \%$ used rubber matts without bedding, and $1.4 \%$ did not use any bedding material at all. A total of $13.9 \%$ of all the herds used rubber matts for a few or all cows, and a total of $5.3 \%$ of the farmers used chopped straw. The average stall age was 13.7 years ( $\mathrm{sd}=9.6$, range 1-63 years). There was an almost significant $(\mathrm{p}=.09)$ negative correlation $(\mathrm{r}=-0.2)$ between age of stall and the general condition of the stall, evaluated on a scale with grade $0=$ very bad condition, and grade $9=$ very good condition with respect to holes and sharp edges. Summer grazing was practized in the majority of the herds $(81.8 \%)$, and among these $43.3 \%$ pastured the cows every day and 
night. The rest (18.2\%) practiced zero-grazing. The average pasture time was 5 months ( $\mathrm{sd}=1$, range 2-7).

\section{The 1994 study}

Only a few herds (15) had mixed types of cattle houses. These herds were excluded from all other tables than Table 1. The neckbar tie was the most commonly used type of tie (Table 2). The majority of the tie stall herds used the cow trainer $(89.1 \%)$ and had partitions between all cows (70.4\%) (Table 2). An open dung channel was the most common type of dung system in the tie stall herds $(60.2 \%)$ (Table 2$)$. The majority of the cubicle house herds had resting cubicles $(94.3 \%)$ and slatted floor (89.1\%) (Table $3)$. Significantly more cubicle house herds had the cows on concrete without bedding $(p=0.002)$ or with saw dust $(p<0.001)$ than tie stall herds (Table 4). The average floor age in the tie stall houses was 20 years $(\mathrm{sd}=12$, range $0-99$ ), and in the cubicle house herds 15 years ( $\mathrm{sd}=7$, range $0-93$ ). There was a significant association between increasing floor age and the farmers' smaller score of being satisfied with the floor $(r=-0.23, p<0.001)$. Heifers were defined as anımals between 12 and 24 months of age. Significantly more herds with cubicle houses for the cows had the heifers in boxes $(p<0.001)$ and less in tie stall houses $(p<0.001)$ (Table 5). Among the herds with deep bed houses, significantly more had the heifers in deep bed houses $(p<0.001)$ and fewer in tie stall houses $(p=0.01)$. The majority of the tethered heifers were kept on concrete with straw or saw dust $(84.2 \%)$, and the majority of box housed heifers were kept on slatted floor without bedding (96.7\%) (Table 6). Cow trainers were only used among heifers in very few herds (14.6\%) (Table 7). Among the herds with cubicle houses, significantly less summer grazed their cows $(p=0.008)$ and more zero-grazed their cows $(p<0.001)$ compared to the other housing
Table 1. Types of cow housing systems among 2148 Danish dairy herds, which participated in a questionnare survey regarding housing system, management, and welfare. The survey was carried out from February to September 1994

\begin{tabular}{lrr}
\hline Type of housing & No herds & $\%$ \\
\hline Tie stall house & 1875 & 873 \\
Cubicle house & 193 & 9.0 \\
Deep bed house & 65 & 30 \\
Combinations & 15 & 0.7 \\
\hline Total & 2148 & 100 \\
\hline
\end{tabular}

Table 2 Type of tie system, use of cow trainer, presence of stall partitions, and type of dung channel among 1875 tie stall herds

\begin{tabular}{lrr}
\hline Stall factor & No herds & $\%$ \\
\hline Type of tie & & \\
Neckbar tie & 1091 & 582 \\
Chain tie & 250 & 133 \\
Yoke tie & 165 & 8.8 \\
Other combination & 369 & 19.8 \\
Total & 1875 & 100 \\
& & \\
Use of cow trainer & & \\
Constant use (more than 10 h a day) & 871 & 46.5 \\
Periodic use & 799 & 42.6 \\
Not in use at all & 203 & 10.8 \\
Did not answer & 2 & 01 \\
Total & 1875 & 100 \\
& & \\
Presence of stall partttons & & \\
Partions between all cows & 1320 & 704 \\
Partions between every 2 cows & 427 & 22.8 \\
No partions between cows & 36 & 1.9 \\
Other or combinations & 91 & 4.9 \\
Did not answer & 1 & 01 \\
Total & 1875 & 100 \\
& & \\
Type of dung channel & & \\
Traditional open dung channel & 1128 & 60.2 \\
Dung channel covered with gratings & 638 & 34.0 \\
Dung channel with slats on top & 80 & 4.3 \\
Combination of types & 28 & 1.5 \\
Did not answer & 1 & 01 \\
Total & 1875 & 100 \\
\hline & &
\end{tabular}


Table 3. Types of cubicles and floors among 193 herds with cubicle houses.

\begin{tabular}{lrr}
\hline Cubicle house factor & No herds & $\%$ \\
\hline Type of cubicle & & \\
Resting cubicle & 182 & 94.3 \\
Feeding cubicle & 11 & 5.7 \\
Total & 193 & 100 \\
& & \\
Type of floor & 172 & 89.1 \\
Slatted floors & 19 & 9.8 \\
Concrete floors & 2 & 10 \\
Both slatted floors and concrete floors & 193 & 100 \\
Total & & \\
\hline
\end{tabular}

systems (Table 8 ). More herds with deep bed houses had their cows outside during winter, either on pasture $(\mathrm{p}<0.001)$ or in an exercise area $(p<0.001)$ than herds from the other housing systems, where almost no cows were outside during winter (Table 8). More farmers with box housed heifers $(p<0.001)$ and fewer farmers with tethered heifers $(p<0.001)$ practized zerograzing than farmers with deep bed houses (Table 9). More herds with deep bed houses had the heifers outside during winter, either on pasture $(\mathrm{p}<0.001)$ or in an exercise area $(\mathrm{p}<0.001)$ compared to herds with the other housing

Table 4. Types of lying area for cows in 1875 tie stall herds and 193 cubicle house herds

\begin{tabular}{lrrrrrr}
\hline \multirow{2}{*}{ Type of lying area } & \multicolumn{2}{c}{ Tie stall house } & & \multicolumn{2}{c}{ Cubicle house } \\
\cline { 2 - 3 } \cline { 6 - 8 } & No herds & $\%$ & & No herds & $\%$ \\
\hline Concrete with straw & 1570 & 83 & & 139 & 72.0 \\
Rubber mats without bedding & 88 & 4.7 & & 12 & 62 \\
Concrete without bedding & 73 & 3,9 & & $17^{*}$ & 8.8 \\
Rubber mats with straw & 57 & 3.0 & & 4 & 21 \\
Concrete with saw dust & 47 & 25 & & $18^{*}$ & 9.3 \\
Rubber mats with saw dust or other bedding & 6 & 03 & & 2 & 1.0 \\
Did not answer & 34 & 1.8 & & 1 & 05 \\
\hline Total & 1875 & 100 & & 193 & 100 \\
\hline
\end{tabular}

* $\mathrm{p} \leq 0002$

Table 5. Housing system for the heifers by the type of housing for the cows. Heifers were defined as anımals between 12-24 months of age

\begin{tabular}{|c|c|c|c|c|c|c|c|c|}
\hline \multirow{3}{*}{ Type of helfer house } & \multicolumn{6}{|c|}{ Type of cow house } & & \\
\hline & \multicolumn{2}{|c|}{ Tie stall house } & \multicolumn{2}{|c|}{ Cubicle house } & \multicolumn{2}{|c|}{ Deep bed house } & \multicolumn{2}{|c|}{ Total } \\
\hline & No herds & $\%$ & No herds & s \% & No her & is $\%$ & No herds & s $\%$ \\
\hline Boxes with slatts & 781 & 417 & $132 *$ & 684 & 25 & 38.5 & 938 & 44.0 \\
\hline Tie stall house & 750 & 40.0 & $30 *$ & 15.5 & $13 *$ & 20.0 & 793 & 372 \\
\hline Deep bed house & 139 & 7.4 & 12 & 6.2 & $22 *$ & 33.8 & 173 & 81 \\
\hline Combinations & 192 & 102 & 19 & 9.8 & 5 & 77 & 216 & 101 \\
\hline No answer or did not have heifers indoor & 13 & 0.7 & 0 & 0.0 & 0 & 00 & 13 & 06 \\
\hline Total & 1875 & 100 & 193 & 100 & 65 & 100 & 2133 & 100 \\
\hline
\end{tabular}

*: $p \leq 001$ 
systems, where almost no heifers were outside during winter (Table 9). On the farms where the cows were pastured during summer, the average pasture time was 5.8 months ( $\mathrm{sd}=1.0$, range 1 12). Stone bruises occurred seldom, and there was no difference between the housing systems (Table 10). The average walking distance for a cow on pasture was $119 \mathrm{~m}(\mathrm{sd}=173$, range 1 $1500 \mathrm{~m})$.

\section{Discussion}

Housing systems for the cows

Cattle houses. In the 1988 survey (Anon. 1988b), $92 \%$ of the herds had tie stall houses. Cubicle houses accounted for $6.4 \%$, deep bed houses for $1.4 \%$, and the remaining $(0.2 \%)$ had mixed types of housing. The difference between the 3 surveys indicates a slight change from tie stall houses to the larger loose houses (Table 1). This is in agreement with the fact that the average herd size is increasing (Anon. 1994a). And loose housed herds are usually larger than tied herds. Finally, deep bed houses were twice as common in 1994 as in 1988, while there were only 1 deep bed house among the 156 farms in the 1983 survey.

There are both advantages and disadvantages associated with each type of cattle houses. Broom (1992) mentioned that the good housing system gives the cow control over its environment, is predictable and diverse. This is to some extent favoured in the loose house. The loose house also allows social contact with other cows and the possibility of exploring the environment. A disadvantage for the loose house is a high degree of fecal contamination which may be associated with an increase in the incidences of claw disorders (Baggott \& Russell 1981, Peterse, 1992). And there may be a high level of social tension compared to grazing (Miller \& Wood-Gush 1991), especially if there is a high stocking density (Wierenga 1983).

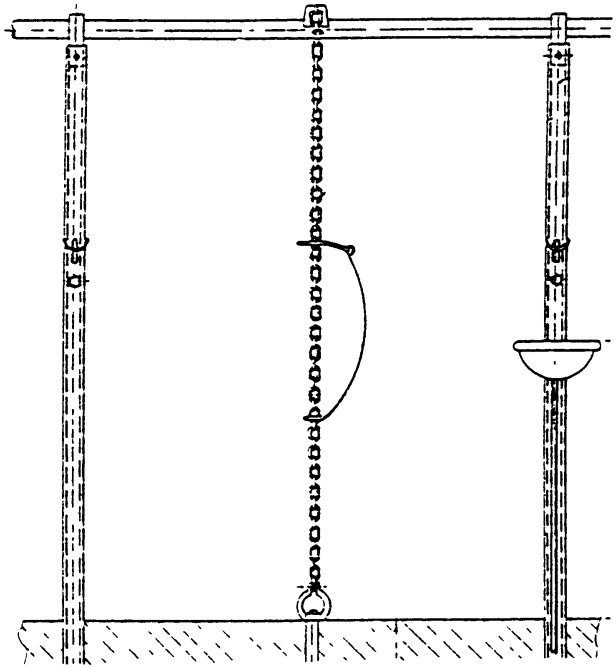

F1gure 1. Chain tie (Mortensen 1971, with permission)

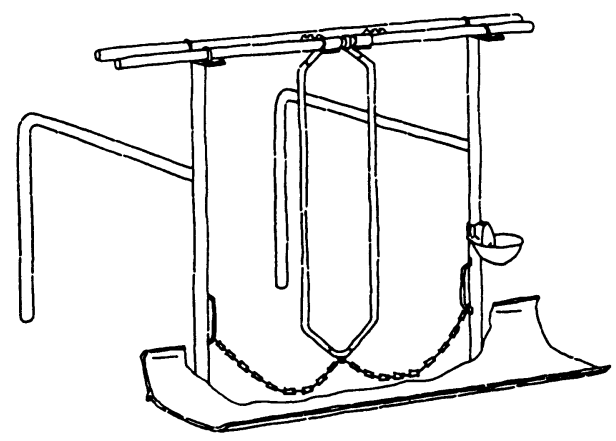

Figure 2 Yoke tie (Rom 1995, with permission)

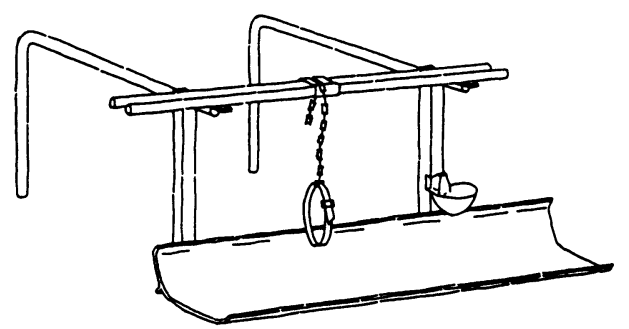

Figure 3. Neckbar tie (Rom 1995, with permission). 
Table 6. Type of lying area for the heifers among 793 dairy herds with tethered heifers and 938 herds with box housed heifers.

\begin{tabular}{lrrrrr}
\hline \multirow{2}{*}{ Type of lyıng area } & \multicolumn{2}{c}{ Tied helfers } & & \multicolumn{2}{c}{ Box housed heifers } \\
& No herds & $\%$ & & No herds & $\%$ \\
\hline Concrete with straw or sawdust & 668 & 84 & & 14 & 1.5 \\
Concrete without bedding & 83 & 10.5 & 8 & 09 \\
Slatted floors without bedding & 29 & 3.7 & 907 & 967 \\
Rubber mats with or without bedding & 9 & 1.1 & & 1 & 0.1 \\
Slatted floors with bedding & 3 & 0.4 & & 5 & 05 \\
Did not answer & 1 & 0.1 & & 3 & 03 \\
\hline Total & 793 & 100 & & 938 & 100 \\
\hline
\end{tabular}

Table 7. Use of cow trainer among tethered heifers in 793 dairy herds.

\begin{tabular}{lrr}
\hline Use of cow trainer for the heifers & No herds & $\%$ \\
\hline Not in use at all & 677 & 85.4 \\
Constant use (more than 10h a day) & 57 & 7.2 \\
Periodic use & 59 & 7.4 \\
\hline Total & 793 & 100 \\
\hline
\end{tabular}

The farmer and his cows are generally in closer contact in the tie stall house. This provides a better opportunity to observe disease. But the tie stall house is a restrictive environment compared to the loose house. Krohn \& Munksgaard (1993) found that lying down took significant longer time for tethered cows than for loose housed cows. And tethered cows may have re-

Table 8 Grazing procedures for the cows during summer and winter by the type of housing system for the cows.

\begin{tabular}{|c|c|c|c|c|c|c|c|c|}
\hline \multirow{2}{*}{$\begin{array}{l}\text { Grazıng procedures } \\
\text { for the cows }\end{array}$} & \multicolumn{2}{|c|}{ Tie stall house } & \multicolumn{2}{|c|}{ Cubicle house } & \multicolumn{2}{|c|}{ Deep bed house } & \multicolumn{2}{|c|}{ Total } \\
\hline & No herds & $\%$ & No. herds & s \% & No herds & s \% & No herds & $\%$ \\
\hline \multicolumn{9}{|l|}{ Summer } \\
\hline Grazıng & 1440 & 76.8 & $117^{*}$ & 60.6 & 57 & 877 & 1614 & 75.7 \\
\hline Zero-grazing & 343 & 18.3 & $60^{*}$ & 311 & 6 & 92 & 409 & 19.2 \\
\hline Only dry cows & 77 & 4.1 & 7 & 36 & 0 & 0.0 & 84 & 3.9 \\
\hline Exercise area & 8 & 04 & 8 & 4.1 & 2 & 31 & 18 & 0.8 \\
\hline Other & 7 & 0.4 & 1 & 0.5 & 0 & 0.0 & 8 & 04 \\
\hline Total & 1875 & 100 & 193 & 100 & 65 & 100 & 2133 & 100 \\
\hline \multicolumn{9}{|l|}{ Winter } \\
\hline Zero-grazıng & 1850 & 98.7 & 190 & 98.4 & 54 & 831 & 2094 & 982 \\
\hline Grazıng & 11 & 0.6 & 0 & 0.0 & $8^{*}$ & 12.3 & 19 & 09 \\
\hline Exercise area & 9 & 0.5 & 3 & 1.6 & $3^{*}$ & 46 & 15 & 07 \\
\hline Other & 5 & 0.3 & 0 & 0.0 & 0 & 0.0 & 5 & 0.2 \\
\hline Total & 1875 & 100 & 193 & 100 & 65 & 100 & 2133 & 100 \\
\hline
\end{tabular}

$*: \mathrm{p} \leq 0.008$. 
Table 9. Grazıng procedures for the heifers during summer and winter by the type of housing system for the heifers

\begin{tabular}{|c|c|c|c|c|c|c|c|c|}
\hline \multirow{2}{*}{$\begin{array}{l}\text { Grazing procedures } \\
\text { for the heifers }\end{array}$} & \multicolumn{2}{|c|}{ Tie stall house } & \multicolumn{2}{|c|}{ Cubicle house } & \multicolumn{2}{|c|}{ Deep bed house } & \multicolumn{2}{|c|}{ Total } \\
\hline & No herds & $\%$ & No herds & $\%$ & No herds & $\%$ & No herds & $\%$ \\
\hline \multicolumn{9}{|l|}{ Summer } \\
\hline Grazıng & 761 & 960 & 805 & 85.8 & 160 & 92.5 & 1726 & 90.6 \\
\hline Zero-grazıng & $30^{*}$ & 3.8 & $121 *$ & 129 & 10 & 5.8 & 161 & 8.5 \\
\hline Exercise area or other & 2 & 0.3 & 12 & 13 & 3 & 17 & 17 & 0.9 \\
\hline Total & 793 & 100 & 938 & 100 & 173 & 100 & 1904 & 100 \\
\hline \multicolumn{9}{|l|}{ Winter } \\
\hline Zero-grazıng & 780 & 984 & 927 & 98.8 & 154 & 890 & 1861 & 97.7 \\
\hline Grazing & 8 & 10 & 5 & 05 & $12 *$ & 69 & 25 & 13 \\
\hline Exercise area or other & 4 & 05 & 1 & 01 & $7 *$ & 40 & 12 & 06 \\
\hline Did not answer & 1 & 0.1 & 5 & 05 & 0 & 0.0 & 6 & 03 \\
\hline Total & 793 & 100 & 938 & 100 & 173 & 100 & 1904 & 100 \\
\hline
\end{tabular}

* $\mathrm{p}<0001$.

duced possibility of grooming their back part depending on the tie system (Munksgaard \& Krohn 1990). Hock lesions are also common in inadequately designed tie stalls (Thysen 1987, Krohn \& Munksgaard 1993, Alban et al. 1995). Regarding construction of new cattle houses, The National Committee on Danish Cattle Husbandry recommends loose houses for large herds, because they comply better with the cows' need for social behaviour and freedom of movement than the tie stall houses (Thøgersen 1995).

Tie systems in the tie stall house. In the 1988 survey, $43 \%$ of the herds had neckbar tie, while $14 \%$ had chain tie, and $12 \%$ yoke tie. The difference between the 3 surveys indicates that many farmers install neckbar ties when they change tie system (Table 2). From a welfare point of view, this is a positive trend, since the other ties are considered to be less suitable. E.g. Mortensen (1971) found that the chain tie and the yoke tie restricted the cow's natural rising and lying. Blom (1981) found that the yoke
Table 10 Occurrence of stone bruising of the claws based on the farmers' memory Only herds which practiced summer grazıng were included

\begin{tabular}{lrr}
\hline Occurrence & No herds & $\%$ \\
\hline Never happened & 589 & 365 \\
Seldom & 972 & 60.2 \\
Frequent & 50 & 31 \\
Did not answer & 3 & 01 \\
\hline Total & 1614 & 100 \\
\hline
\end{tabular}

tie was associated with lameness. And Munksgaard \& Krohn (1990) found that the yoke tie restricted the cow's movement, hindered the cow in rising and lying, and reduced the possibility of grooming.

Cow trainer. In the 1988 survey, $29 \%$ of the herds used the cow trainer constantly, $48 \%$ in periods, and $23 \%$ did not use it. The results of the 3 surveys may indicate that more farmers use the cow trainer today compared to 1983 and 1988 (Table 2). The function of the cow trainer is to force the cow back when it defecates, and, 
hence, improve the cleanliness of the stall and the claw health (Bergsten \& Pettersson 1992). Some authors found that the cow trainer had a negative impact on the cows behaviour (Lefcourt et al. 1986, Kohli 1987), while others found no effect (Metzner \& Groth 1992, Simensen \& Bøe 1988). Regarding health, diverging results exists as well. Some authors found improved health (Bergsten \& Petterson 1992, Matzke et al. 1992), while others found no or even a negative effect on the health (Bakken 1982, Alban et al. 1995). Since 1988 in Sweden, it has been prohibited to install or use a cow trainer in new tie stalls, and the use of cow trainers in already existing tie stalls was phased out by the end of 1993 (Anon. 1994b). If a farmer wants to use the cow trainer, the Danish recommendations should be followed to minimize the possible negative impact of the cow trainer: correctly placed ( $\geq 5 \mathrm{~cm}$ above the cow's back), daily checked, switched off in longer periods, and not used for ill animals, cows in heat, cows in late pregnancy, or steers in boxes (Anon. 1991).

Stall partitions in the tie stall houses. Unfortunately, no information was available on this subject in the 1988 survey. A comparison of results from the 1994 and the 1983 survey indicates that many more herds have partitions between all cows in 1994 (Table 2). From a welfare point of view this is a positive trend, since the partitions may reduce the incidence of teat injuries (Näsi \& Saloniemi 1981, Bakken 1982, Matzke et al. 1992).

Type of dung channel system in the tie stall houses. Since 1983 it has become more common to have gratings over the dung channel. It was observed that the open dung channel system may provide less draught and urine splash in the stall than the other types with gratings or slats over the dung channel. Therefore, the open dung channel may provide a better environment for the cow. But further work is needed on this subject.

The cubicle and the floor type in the walking area in the cubicle house. There was no information on these subjects in the 1983 or the 1988 surveys. Therefore, no inference can be made about a trend in the development. Regarding type of cubicle, the only conclusion which can be drawn is, that only a few herds had feeding cubicles in 1994 (Table 3). From a welfare point of view this is positive, since the feeding cubicle is known for poor hygiene (Rådum et al. 1982). Regarding floor type, slatted floor was by far the most common kind of floor in 1994 (Table 3). The welfare impact of the different kinds of floor types is difficult to judge, since detailed information is needed on e.g. the maintenance level of the floor, and for slatted floor, the width of the slats and the opening between the slats. But as a general judgment, Blom (1982), Buchwald et al. (1982) and Thysen (1987) found that a solid concrete floor may lead to more incidences of lameness compared to slatted floor. Hence, it is positive that there were only few cubicle houses with solid floor in 1994.

Type of lying area. In the 1988 survey, $84 \%$ of the farmers used straw as bedding, $6 \%$ used saw dust, while $10 \%$ did not give bedding at all. It appears that the proportion of farmers giving bedding to the cows was unchanged in 1994 (Table 4) compared to 1988, but it was less than in 1983. Saw dust was almost not in use in 1983, in 1988 it was more common, and in 1994 it was less common again (Table 4). From a welfare point of view, the low use of saw dust is positive, since use of saw dust is supposed to have a negative impact on the udder health (Schmidt et al. 1985). A well-bedded resting area provides the best opportunities to 
maintain a good health (Schmidt et al. 1985, Ekesbo 1966), and as an example, Krohn \& Munksgaard (1993) found that tramped teats may be a result of too little or no bedding. Furthermore, Singh et al. (1993) found, that cows lay down for longer periods in deep bed houses compared to cubicle houses probably because they preferred the comfortable lying surface. The use of chopped straw was much more common in 1994 compared to 1983. Chopped straw is used by some farmers because it is able to pass through the openings between grates or slates. Schmidt et al. (1985) found that chopped straw had the same absorption capacity as notchopped straw, and therefore, there should be no welfare implications for the use of chopped straw.

In both the 1983 study and the 1994 study there was a negative correlation between floor age and the general condition of the floor. The low correlation $\left(r^{2} \approx 0.05\right)$ indicates that quality and maintenance are more important than the age of the floor.

\section{Housing system for the heifers}

Housing and type of lying area. In the 1988 survey, loose houses - including deep bed houses - accounted for half of the herds, while the tie stall houses were used in the other half of the herds. It is not possible to make a closer comparison between the surveys, since the results of the 1988 survey were not presented in detall, and no information on this subject was available from the 1983 survey. Regarding type of lying area for heifers, the 1983 survey did not cover this subject. In the 1988 survey, the percentage of farmers which used bedding for the loose housed heifers was not mentioned, while it was stated that $86 \%$ of the herds with tethered heifers used bedding. Hence, no change has probably taken place among the tie stall farmers (Table 6). Among the loose housed heifers, the majority were kept in boxes on slatted floors without bedding. Boxes provide young cattle with an opportunity for social contact with other animals of the same species - which they have a strong need for (Broom 1982). But a high stocking density should be avorded, since it is associated with high risk of tramped tails which may need amputation (Madsen et al. 1987). Both from a welfare point of view and to $1 \mathrm{~m}$ prove production, boxes with a bedded resting area and a not-bedded walking area are recommended for heifers. (Anon. 1991, Thøgersen 1995).

Cow trainer for heifers. No information on this subject was available in the 1983 survey. In the 1988 survey, $11 \%$ of the herds used the cow trainer for the heifers. Compared to the 1988 survey, there may have been a slight increase in the use of cow trainers for heifers (Table 7). It is our belief, that the cow trainer is less suitable for the heifers than for the cows, because young animals in general are more nervous than older ones.

\section{Grazing}

Cows on pasture - during summer. In the 1988 survey, $72 \%$ used summer grazing, $23 \%$ zero-grazing, $3 \%$ exercise area, and the rest $(2 \%)$ used other procedures. Hence, from 1988 to 1994, there has been a trend towards increased use of summer grazing (Table 8). But compared to 1983 , fewer herds practiced summer grazing in 1994. From a welfare point of view, the increased tendency to let the cows graze is positive, since grazing, generally speaking, is associated with better health and reproduction (Ekesbo 1966, Kristensen et al. 1986, Krohn 1986, Krohn \& Rasmussen 1992, Gustafson 1993). The positive effect is probably due to both grazing, sunshine, and fresh air. Freedom of movement is important too, since it allows the animals to perform a wide range of species-specific behaviours. Furthermore, the negative effects of a less suitable 
housing system are minımized by daily exercise. It should be mentioned, that summer grazing is compulsory in organic Danish cattle keeping (Anon. 1994c). As well, The National Committee on Danish Cattle Husbandry recommends that tie stall cows should have the possibility for exercise either by use of summer grazing or in an exercise area (Thøgersen 1995).

Cows on pasture - during winter. No information on this subject was available in the 1988 survey. In the 1983 survey the cows were pastured for a maximum of 7 months. This indicates that winter grazing was not in use at all in 1983. In 1994, winter grazing was almost only used in deep bed herds (Table 8). The Danish Veterinary Health Board has, in the light of the Danish law for protection of animals, specified that animals which are kept outside during winter should have access to shelter, a dry bedded lyıng area, and be provided with supplemental food and fresh water (Nielsen, personal comm. 1994). The deep bed houses are often constructed in such a way that the cows may walk in and out freely. In this way, the Health Board's recommendations can be followed eas1ly. This may explain why it was almost only the deep bed farms which practiced winter grazing. It can be expected that, in particular the tied cows, may benefit from exercise during winter, and this can be provided by use of an exercise area. It should be mentioned that in the organic Danish cattle farming, all animals should have the possibility for regular exercise during winter (Anon. 1994c).

Heifers on pasture - during summer. There was no information on this subject in the 1983 survey. In $1988,91 \%$ of the farmers had the heifers on pasture and $6 \%$ practiced zerograzing during summer. This is almost the same as the 1994 survey (Table 9). Under the assumption that grazing has the same effect on heifers as on cows, the common use of summer grazing is positive, and the relative high use of zero-grazing among box housed heifers is unfortunate. Foldager et al. (1993) found that summer grazing had a positive impact on the development of the heifers' motorical system, the ease of handling, and later on the ease of milking. Furthermore, the National Committee on Danısh Cattle Husbandry states that heifers should be grazed at least one season during the rearing period (Thøgersen 1995).

Heifers on pasture - during winter. Winter grazing was not mentioned either in the 1983 survey or in the 1988 survey. Among the 1994 herds, winter grazing of heifers was almost only seen in deep bed herds (Table 9). Again, this may be related to the ease at practize grazıng in deep bed houses. The recommendation for cows on pasture during winter is also valid for the heifers.

Walking distance and problems with stone bruising of the claws. No information was available on these subjects in the surveys from 1983 og 1988. Danish dairy cows do not have to walk very far to reach the field, compared to how long they walk on the field, and only a few herds had frequent problems with stone bruising (Table 10). Cows walk longer on the field, e.g. Krohn et al. (1992) found that cows with free access to grazing areas would walk 2.0-3.4 km per day during summer time. Furthermore, Gustafson (1993) concluded that "exercise for $0.5-3 \mathrm{~km}$ per day had a significantly positive effect on the health of the cows around calving". Chesterton et al. (1989) found that the track maintenance level was associated with lameness in dairy cows. Therefore, the conclusion may be, that exercise has a positive effect on the cows' health and reproduction - given the path is maintained. If it is difficult to maintain the path, an exercise area, e.g. made of concrete, may be an alternative way of providing exercise for the cows. 
General points with questionnaire data. The possibility of bias in a questionnaire survey is discussed in an adjacent paper (Alban \& Agger 1996).

\section{Conclusion}

It is the farmer who is in daily contact with the cows - not the veterinary practitioner or the agricultural advisor. Hence, to improve welfare, means should be taken to inform farmers about welfare aspects of housing systems and grazing procedures. The results show that generally speakıng the Danish dairy farmers in 1994 follow the common recommendations: 1) there are partitions between stalls in almost all tie stall houses, 2) feeding cubicles are seldomly seen in cubicle houses, 3) bedding is provided for most cows, 4) saw dust as bedding for cows is not commonly used, and 5) the majority of cows and heifers are pastured during summer. However, adjustments in the following areas would be appropriate: 1) tie systems which restrict the cow's rising and lying should be phased out, and 2) bedding should be provided for the loose housed heifers in boxes.

\section{Acknowledgements}

The authors want to thank Chrıstına Ejlersen, Annelise Ito, and Lartey Lawson for excellent technical assistance. Mette Vaarst, Thomas Færgeman, and Jens Yde Blom are acknowledged for instructive comments to the manuscript. Finally, the Danish Agricultural Advisory Center is acknowledged for their cooperation in the project The project was financed by the Danish Ministry of Agriculture, grant no. VEL92-KVL-8

\section{References}

Agger JF Pattelæsion og klovlidelser hos malkekøer. (Teat lesion and claw diseases in dairy cows). Ph.D -thesis, The Royal Veterinary \& Agricultural University, Frederıksberg, Denmark, 1981, $292 \mathrm{pp}$

Agger JF Production diseases and mortality in dairy cows: analysis of records from disposal plants from 1960-1982. Proc. 5th Intern Conf. on Prod.
Dis in Farm Anımals Uppsala, Sweden, 10-12 August 1983, pp 308-311.

Agger JF, Alban L Welfare in Danısh Dairy Herds 3 Health Management and General Routines in 1983 and 1994 Acta vet. scand. 1996, 37, 79-97.

Agger JF, Willeberg $P$ Production and mortality in darry cows from 1960-1991 Time series analysis of ecological data Proc. 6th ISVEE. Ottawa, Canada, 12-16 August 1991, pp. 357-360.

Alban L, Agger JF Welfare in Danısh Dairy Herds 1. Disease Management Routınes in 1983 and 1994. Acta vet. scand. 1996, 37, 49-63

Alban L, Agger JF, Lawson LG Lameness in tied Danish dairy cattle - the possible influence of housing systems, management, milk yield, and prior incidents of lameness. Prev. vet. Med 1996 (accepted)

Anon Betænkning om Intensive Produktionsformer inden for Landbruget Justıtsministeriet (Intensive production forms in animal husbandry. The Danish Ministry of Justice) Report No 1126 Copenhagen, Denmark, 1988a, 152 pp

Anon Produktionssystemer og Produktionsmetoder 1 Kvægbruget Landskontoret for Kvæg. (Production systems and production methods in the cattle husbandry The Danısh National Department of Cattle Husbandry). Århus, Denmark, 1988b, 17 pp

Anon Indretning af Stalde tıl Kvæg - Danske Anbefalınger. Landbrugets Rådgivnıngscenter (Organization of housing systems for cattle - Danish recommendations. The Danish National Adv1sory Center). Århus, Denmark, 1991, 96 pp.

Anon Landøkonomısk Oversigt 1994. De Danske Landboforeninger (Agricultural Survey 1994 The Danısh Farmers' Union). Copenhagen, Denmark, 1994a, p. 157

Anon Elektriska kodressörer. Jordbruksverket. (Electrical cow trainers. The Swedish National Board of Agriculture). Jönkopıng, Sweden, 1994b, $27 \mathrm{pp}$.

Anon. Vejledning om økologisk jordbrugsproduktion. Landbrugsministeriet, Plantedirektoratet. (Instructions in organic farming. The Danish Ministry of Agriculture, The Plant Directorate) Copenhagen, Denmark, 1994c, 11-15

Baggott DG, Russell AM Lameness in Cattle. $\mathrm{Br}$ Vet J. 1981, 137, 113-132

Bakken $G$ The Relationship between Environmental Conditions and Bovine Udder Diseases in Norwegian Dairy Herds. Acta Agric. Scand. 1982, $32,23-31$. 
Bergsten $C$, Pettersson $B$ The cleanliness of cows tied in stalls and the health of their hooves as influenced by use of electric trainers. Prev. vet Med. 1992, 13, 229-238.

Blom JY Tryknınger og andre fysıske skader på malkekøer. (Contusions and other physical injuries on dairy cows in different housing systems ) In Østergaard V, Hindhede J (eds) · Report No. 515 Natl. Inst. Anim. Sc1., Denmark, 1981, 73-104.

Blom JY Forekomst af klınıske klovlidelser hos malkekøer 1 forskelligt staldmiljø (Occurrence of clinical lameness in dairy cows in different housing systems.) In. Østergaard V, Hindhede J (eds): Report No. 532 Natl Inst Anım Sc1., Denmark, 1982, 128-140.

Broom DM Husbandry methods leading to inadequate social and maternal behaviour in cattle. In. Disturbed behaviour in farm animals Hohenheimer Arbeiten 1982, 121, 42-51.

Broom DM Welfare. In: Andrews AH, Blowey RW, Boyd H, Eddy RG (eds): Bovine Medicine. Blackwell Scientific Publications. Oxford, Great Britain, 1992 pp. 768-778

Buchwald E, Blom JY, Smedegaard HH, Thysen I Klovsundhedens afhængighed af gulvtype og lejetype. (The association between claw health and floor type and type of resting area ) In. Østergaard V, Hindhede J (eds). Report No. 532 Natl Inst Anım. Scı., Denmark, 1982, 109-127.

Chesterton RN, Pfelffer DU, Morris RS, Tanner CM Environmental and behavioural factors affecting the prevalence of foot lameness in New Zealand dairy herds - a case control study. N. Z vet. J. 1989, 37, 135-142.

Christensen $R$ Log-lınear models Sprınger-Verlag. Berlın, Germany, 1990. 408 pp.

Ekesbo I Disease incidence in tied and loose housed dairy cattle. Acta agr. scand. 1966, Suppl 15, 79 pp

Foldager J, Krohn CC, Rasmussen MD. Kvier opstaldet 1 bindestald eller spaltegulvsboks med og uden sommergræsnıng (Replacement heifers in tie stalls or boxes with slatted floor with and without summer grazing). Research Report No. 10 Natl Inst. Anım Sc1., Denmark, 1993, 53 pp.

Gustafson GM Effects of daily exercise on the health of tied dairy cows. Prev. vet Med. 1993, 17, 209223

Kohll, $E$ Auswirkungen des Kuhtrainers auf das Verhalten von Milchvieh. (The effect of the cow trainer on the behaviour of dairy cows). Schweiz. Arch Tierheilk 1987, 129, 23-25.
Kristensen ES, Henneberg U, Hindhede J Sommerfodringssystemets indflydelse på malkekoens produktion og økonomi. (The summer feeding system's effect on the dairy cow's performance and economy). In: Østergaard V, Hindhede J (eds): Report No. 615 Natl Inst Anım Sc1., Denmark, 1986, 26-51

Krohn CC Motion for malkekøer 1 bindestalde. (Exercise for dairy cows in tie stall houses ) Ugeskrift for Jordbrug, 1986, 46, 1364-1366.

Krohn CC, Munksgaard L Behaviour of dairy cows kept in extensive (loose housing/pasture) or intensive (tie stall) environments Appl Anım. Beh. Sc1. 1993, 37, 1-16

Krohn CC, Rasmussen MD Malkekøer under ekstremt forskellige produktionsbetingelser Ydelse, tılvækst, reproduktion, sundhed og holdbarhed. (Dairy cows under extreme conditions productivity, reproduction, health, and stayabil1ty). Report No 709 Natl Inst. Anım. Sc1, Denmark, 1992, $52 \mathrm{pp}$

Krohn CC, Munksgaard L, Jonasen B Behaviour of dairy cows kept in extensive (loose housing / pasture) or intensive (tie stall) environments. I. Experimental. procedure, facilities, tıme budgets diurnal and seasonal conditions Appl. Anim. Beh Sc1. 1992, 34, 37-47.

Lefcourt AM, Kahl, S, Akers, RM Correlation of indices of stress with intensity of electrical shock for cows J. Dairy Sc1 1986, 69, 833-842

Madsen EB, Thysen I, Ingvartsen $K L$, Østergaard $V$. Ungtyres sundhed og produktion ved forskellig belægning 1 spaltegulvsbokse (Health and production of young bulls at different stocking rates on slatted floor). In: Østergaard V, Hindhede J (eds): Report No 628 Natl. Inst Anım Sc1, Denmark, 1987, 209-218

Matzke P, Holzer A, Deneke J Ein Beitrag zum Einfluss von Umweltfaktoren auf das Vorkommen von Eutererkrankungen (A contribution to the influence of environmental factors on the inc1dence of udder diseases). Tierärztl. Prax. 1992 , 20 21-32.

Metzner $C$, Groth $W$ : Der Einfluss des Kuhtrainers auf das Verhalten und auf Kresslauf- und Blutparameter der Kuh. (The effect from the cow trainer on the behaviour and on circulatory and blood parameters in the cow) Zuchtungsk 1992, 51, 85-95

Miller K, Wood-Gush DGM: Some effects of housing on the social behaviour of dairy cows Anim. Prod 1991, 53, 271-278 
Mortensen $B$ Forsøg med bindsler til køer (Tests of cow ties) SBI-Landbrugsbyggen No 33, Denmark, 1971, $156 \mathrm{pp}$

Munksgaard L, Krohn CC Koens nærmiljø Adfærd og trykpåvırkninger 1 relation til udformnıng af foderbord og bindselstype. (Constructions of tiestalls for dairy cows Behaviour and pressure recordings at different tie-systems and constructions of the manger) Report No 682 Natl Inst Anım. Sc1., Denmark, 1990, 31 pp

Nielsen $K$ Charman of the Danish Veterinary Health Board. The Veterınary and Agricultural University Frederiksberg, Denmark. Personal comment, January 1994.

Nàsı M, Saloniemı $H$ Effect of environmental change on injuries of udder and legs in dairy cows. Nord. Vet -Med. 1981, 33, 185-193.

Peterse DJ Foot lameness. In: Andrews AH, Blowey RW, Boyd H, Eddy RG (eds) Bovine Medicıne. Blackwell Scientific Publications Oxford, Great Britain, 1992, 353-363

Rom HB Danısh Institute of Anımal Science, Research Centre Bygholm, Horsens, Denmark, 1995

Rådum A, Mortensen B, Olsen $\mathrm{N}-\mathrm{O}$ Fodersengestalde (Feeding cubıcles). SBI-meddelelser No 18, Statens Byggeforskningsinstitut. Denmark, $1982.31 \mathrm{pp}$

Schmidt M, Jørgensen M, Møller-Madsen Aa, Jensen $H$, Horváth Z, Keller P, Konggaard SP Halm som strøelse tıl malkekøer (Straw as bedding for dairy cows) Report No. 593 Natl Inst Anim Sc1, Denmark, 1985, 90 pp.

Simensen E, Bøe $K$ Effekt av kutreneren på renholdet, kyrnes atferd og plasmakonsentrasjon av cortisol. (The effect of the cow trainer on the cleanliness, the cows' behaviour, and the plasma concentration of cortisol) Aktuelt fra Statens fagtjeneste for landbruget Ås, Norge, 1988, 7277.

Simonsen $H B$ Vurdering af dyrs velfærd (Assessment of anımal welfare). In Etık, Velfærd og Adfærd 1 Husdyrbruget (Ethics, welfare, and behaviour in anımal husbandry) The Danısh Instıtute for Agricultural Information Århus, Denmark, 1993, 17-28.

Singh SS, Ward WR, Lautenbach K, Murray RD Be- haviour of lame and normal dairy cows in cubicles and in a straw yard Vet Rec. 1993, 133, 204208.

Thysen I Foot and leg disorders in dairy cattle in different housing systems. In Wierenga $\mathrm{HK}$, Peterse DJ (eds): Cattle housing systems, lameness, and behaviour. Martınus Nijhoff Publishers, The Netherlands, 1987, 166-178

Thøgersen $R$ Integreret kvægproduktion med speciel fokus på sundhed og velfærd. (Integrated cattle production with emphasis on health and welfare). In: Proceedings from Dansk Boologisk Selskab. Denmark, September, 1995, II.3 1II.3.6.

Tinggaard $M$ (ed) Dyrevelfærd under lup. (Anımal welfare in focus). (several authors). Jord og Viden, 139, No 19, September 22nd, 1994, 28 $\mathrm{pp}$

Wierenga $H K$ The influence of the space for walking and lying in a cubicle system on the behaviour of darry cattle. In Baxter SH, Baxter MR, MacCormack JAC (eds): Farm anımal housıng and welfare. Martınus Nijhoff Publishers The Netherlands, 1983, 171-180

\section{Sammendrag}

Velfard 1 danske malkekvagbesatninger 2 Staldsystemer og groesningsrutiner I 1983 og 1994

Denne artıkel præsenterer anden del af et rundspørge udført 12148 danske malkekvægbesætnınger 11994 samt resultater af en lignende undersøgelse fra 1983. Staldsystemet og græsnıngsrutınens betydnıng for velfærden diskutteres, ligesom status og udvikling gennem de 11 år kommenteres Resultaterne viser, at generelt set følger danske mælkeproducenter anno 1994 de gældende anbefalınger- 1) Der er båseadskıllelse mellem hver bås 1 næsten samtlige bindestalde, 2) fodersengebåse er 1kke særligt udbredte, 3) de fleste køer har strøet leje, 4) savsmuld som strøelse bruges kun af få, og 5) de fleste mælkeproducenter har både køer og kvier på græs om sommeren. Ændringer på følgende områder vil dog være hensigtsmæssige 1) Bindsler, som hindrer koen 1 at rejse og lægge sig naturligt, bør udfases, og 2) boksopstaldede kvier bør have adgang tıl strøet leje

(Recelved June 30, 1995, accepted November 1, 1995)

Reprints may be obtained from $\cdot$ L Alban or JF Agger, Department of Anımal Science and Anımal Health, Division of Ethology and Health, The Royal Veterınary \& Agricultural Unıversity, Bulowsvej 13, DK-1870 Frederıksberg C, Denmark. E-ma1l: JFA@KVL.DK, Fax: +4535283022 